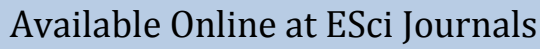 \\ International Journal of Phytopathology \\ ISSN: 2305-106X (Online), 2306-1650 (Print)
}

http://www.escijournals.net/phytopathology

\section{CHARACTERIZATION OF WHEAT GENOTYPES AS SOURCES OF ICE NUCLEATION ACTIVE BACTERIA FOR BIOPRECIPITATION AEROSOLS}

\author{
aAbd-Alrahman Moukahel, aSiham Asaad, bBakri Debbes, ${ }^{\mathrm{c}, \mathrm{d} C i n d y}$ E. Morris, dDavid C. Sands \\ ${ }^{a}$ The International Center for the Agriculture Research in the Dry Areas (ICARDA), Aleppo, Syria. \\ ${ }^{b}$ Department of Plant Protection, Aleppo University, Aleppo, Syria. \\ c INRA, UR0407 Pathologie Végétale, F-84143 Montfavet cedex, France. \\ ${ }^{d}$ Department of Plant Sciences and Plant Pathology, Montana State University, Bozeman, MT 59717-3150, USA.
}

\section{A B S T R A C T}

As water resources become more and more scarce, production of crops under dry land conditions brings agriculture into potential conflict with other uses of water. There is an emerging awareness that the orientation of the goals of plant breeding can be shifted to create crops that can offset the negative impacts of agriculture on the environment in order to make agriculture more sustainable. Here we have explored the possibility to select lines of wheat, the crop that occupies more land than any individual crop, that contribute to the bioprecipitation cycle. In this cycle the ice nucleation (IN) active component of the microflora on leaves contributes to the ice nuclei in the atmosphere that activate processes in clouds necessary for rainfall. In line with this long term goal, we have deter-mined the capacity of breeding lines of wheat, adapted to dry land conditions, to harbor IN active bacteria. In particular, we focused on Pseudomonas syringae, the most ubiquitous of the IN active bacteria on plants. Because strains of this bacterium can be a plant pathogen, we evaluated the abundance of non-pathogenic IN active strains of $P$. syringae on a range of wheat genotypes from the research program of the International Center for Agricultural Research in the Dry Areas. Of the 25 genotypes of bread wheat examined, leaves of 12 genotypes naturally harbored P. syringae in the field. Eight of these genotypes harbored populations of IN active P. syringae with an impaired Type 3 Secretion System (involved in pathogenicity) as high as 4 x $105105 \mathrm{CFU}$ g-1 of leaf tissue. Three of these 8 wheat genotypes harbored IN active $P$. syringae that were not virulent on either bread or durum wheat and for 1 of these wheat genotypes the strains of IN active P. syringae were virulent on only 1 of the 13 plant species on which pathogenicity was tested. For the wheat geno-types that had $P$. syringae on leaves in the field, bacteria were naturally transmitted to seed but dur-ing seed storage the bacterium could be detected on only half of the genotypes after 3 months of storage. To explore the possibility of enhancing the IN active microflora on leaves, we assessed the capacity of bacteria inoculated on seed to be transmitted to seed. The effectiveness of the trans-mission depended on an interaction of wheat genotype and bacterial strain. Overall, this work points to the possibility of selecting plants with the goal of changing their microflora for purposes other than resistance to plant disease and in this case for the purpose of contributing to processes that could favor rainfall.

Keywords: Pseudomonas syringae, epiphytic bacteria, seed microbiology, bioprecipitation, Syria.

\section{INTRODUCTION}

Dry lands constitute about $20 \%$ of the Earth's land surface and are found on every continent where there is agriculture (Millenium Ecosystem Assessment, 2005). When dry land is cultivated, numerous agronomic practices are put into place to assure sufficient yield in

* Corresponding Author:

Email: davidsands41@yahoo.com

(C) 2015 ESci Journals Publishing. All rights reserved. face of plant disease and of water stress, in particular. Improvement of these agronomic practices, including the creation of disease and drought-tolerant cultivars, depends heavily on the international research network of public institutes and private foundations. Since the advent of international wheat breeding programs in 1944 destined to improve wheat for the developing world, $80 \%$ of the resources dedicated to this effort have been consecrated to improvement of yield and disease 
resistance and $20 \%$ to development of resistance to abiotic stresses (Rajaram 1995). In Eastern and Southern Africa, for example, up to $80 \%$ of the acreage for wheat constitutes improved varieties whereas only $20 \%$ are land races (Heisey and Lantican, 2000) thereby illustrating the impact of this research effort on the traits of the wheat varieties that cover dry land landscapes.

Cultivation of wheat in dry land contexts is highly dependent on and limited by rainfall (Qin et al., 2013). Marked increases in yield can be obtained by supplementing water input to attain a total (rain + irrigation) water input of about 500 to $800 \mathrm{~mm}$. For example, in the loess plains of northern China where annual precipitation ranges from 400 to $650 \mathrm{~mm}$, the addition of 200 to $300 \mathrm{~mm}$ of irrigation increased grain yield by 60 to 100\% (Qin et al., 2013). Likewise in Syria, supplementing rainfall with irrigation to assure a seasonal input of $500 \mathrm{~mm}$ of water enhanced the effect of nitrogen fertilization on yield (Zhang et al., 1998). But as water resources become more and more scarce, irrigation is increasingly challenging. Production of crops under dry land conditions brings agriculture into potential conflict with other uses of water. The important ecosystem service rendered by agriculture (food production) is offset by a marked negative impact on the environment in terms of water consumption.

There is an emerging awareness that the goals of plant breeding should be expanded beyond selecting traits directly linked to food production to encompass various environmental and ecosystem services valuable for sustainable agriculture (Brummer et al., 2011). Cultivated and otherwise-managed land now represents $50 \%$ of the vegetated surface of Earth, having significantly displaced wild and semi-wild vegetated areas (Ellis et al., 2010). Wheat occupies more land than any other individual crop. In Syria, for example, wheat is the most important winter crop, grown on about 1.8 million hectares or on about $32 \%$ of the total cultivated area of that country. Hence, cropped plants in general, and wheat in particular, are in ripe contexts to play roles in plant-mediated ecosystem services not only because of the vast surfaces they occupy but also because they benefit from concerted health management and genetic improvement schemes as well as means to facilitate world-wide distribution of useful genetic resources and of knowledge on agronomic practices.

Plants play an important role in the water cycle, not only as consumers of water but also as sources of atmospheric water vapor and aerosols involved in the physical processes in clouds required to initiate rainfall (Morris et al., 2014). More specifically, the water vapor and microorganisms emitted from their leaves are transported up into clouds where they can have considerable impacts on atmospheric processes that define regional climates. In this light, cultivated plants could be deployed to strategically influence rainfall. Here we have investigated the potential for wheat to be deployed with the intent of contributing to atmospheric aerosols that are favorable for rainfall. In particular, we have assessed the variability of dry land wheat to harbor the ice nucleation (IN) active bacterium Pseudomonas syringae. This bacterium is one of the most efficient naturally-occurring IN active aerosols in the environment. Numerous research reports suggest that $P$. syringae, as well as other IN active microorganisms, can initiate the physical processes in clouds needed for rainfall when they are sufficiently abundant (Morris et al., 2014). Variability of wheat in terms of their leaf surface populations of $P$. syringae would open the possibility to optimize emissions of this bacterium into the atmosphere. We have also assessed the variability of wheat genotypes to deliver the bacterium to leaves from infested seeds. Optimizing this transmission would foster the development of technology for inoculation of seeds with specific strains of $P$. syringae best adapted as colonizers and ice nucleators while respecting plant health considerations.

Agriculture in many regions is very dependent on natural cycles of rainfall. A case in point, Syria, depends on a wide base of varied natural resources extending over five agro-ecological zones differing in total precipitation, soil structure, and water resources such as rivers, springs, dams, and groundwater which supply water for about 851,000 ha ( $61 \%$ of the total irrigated areas). However, precipitation is considered the main source of water needed to maintain the widespread rain fed system of agriculture, which occupies $70 \%$ of the cultivated area in Syria (Karrou et al., 2011). The production of this crop in the Aleppo region represents around $20 \%$ of the total production of the country (Rajaram, 1995). Since the possibility of affecting the climate in a region is our long term objective, by optimizing the release of aerosols of ice nucleating bacteria from a crop, we isolated and characterized a wide range of IN active strains of $P$. syringae from numerous advanced genotypes of bread wheat cultivars grown at Tel Hadya near Aleppo, Syria. 
The population density of IN active bacteria on leaves can vary 1000 to 10000 fold among different plant species (Lindow et al., 1978) and cultivars of the same species (Georgakopoulos and Sands, 1992). For P. syringae in particular, cultivars of snap beans and barley vary 1000 -fold in the population densities of this bacterium that they harbor on leaves (Georgakopoulos and Sands, 1992; Daub and Hagedorn, 1981). For snap beans, these differences when assessed as the number of leaf associated IN active bacteria are associated with quantitative trait loci (Navarro et al, 2007). Studies of the interaction of $P$. syringae with plants have usually focused on damage to crops due to the plant pathogenicity of this group of bacteria. However, about $20 \%$ of the strains of this bacterium naturally occurring with plants and in other environments have little pathogenic potential (Demba-Diallo et al., 2012; Morris et al., 2013) because they possess defects in or variants of the Type 3 Secretion System, generally responsible for injecting virulence factors (called effectors) into hosts thereby conferring pathogenicity, and are therefore or inefficient for this function (Bartoli et al., 2014). Many of these non- or weakly pathogenic strains are IN active nevertheless (Bartoli et al., 2014; Berge et al., 2014). Hence, we were particularly interested to identify genotypes of wheat that could support populations of IN active $P$. syringae with little pathogenic potential.

At present, production of field crops such as wheat and barley are driven by yield considerations. There is growing interest in how crops influence the environment and how the so-called ecological services they render could be improved through breeding (Brummer et al., 2011), but attention has not yet been given to how crops might be selected or bred as sources of ice nucleationactive particles that could influence weather. This study took place in Syria where rainfall is a key determinant of cereal crop production and at a location where hundreds of cultivars of wheat and barley are evaluated annually for agronomic fitness. The objective of our work has been to determine which combinations of bacteria and cereal grain cultivars might result in production of aerosols of ice nucleating bacteria without adversely effecting crop health. Given the portent of climate change and its effect on crop production, this kind of approach may have important ramifications.

\section{MATERIALS AND METHODS}

Plant Materials as Sources of $P$. syringae: To characterize wheat genotypes for their capacity to harbor P. syringae and for their disease sensitivity, 100 bread wheat genotypes were obtained from the bread wheat breeding program at ICARDA in Aleppo, Syria. The seeds from the each genotype were tested for the presence of $P$. syringae using the $\mathrm{KBC}$ selective agar medium (Mohan and Schaad, 1987), a test recommended by the International Seed Testing Association (ISTA, 2008), before planting in the field in December 2010.

The wheat genotypes were planted in the midst of wheat and barley fields at the Tel-Hadya ICARDA field station using an alpha design with three replicates. Each plot was planted in 5 rows (25 cm apart) $150 \mathrm{~cm}$ long. In May 2011, each wheat genotype was scored visually in the field for the presence of bacterial-like symptoms on leaves collected in the field. Random samples of leaves were taken from the leaves of the 25 genotypes that showed bacterial like symptoms on their leaves (Table 1), put in sterilized paper bags and stored at $4{ }^{\circ} \mathrm{C}$ until testing.

To isolate bacteria, the leaf samples were transferred to zip-lock plastic bags and macerated manually in $0.1 \mathrm{M}$ phosphate buffer $\left(8.75 \mathrm{~g} \mathrm{~K}_{2} \mathrm{HPO}_{4}\right.$ and $6.75 \mathrm{~g}$ $\mathrm{KH}_{2} \mathrm{PO}_{4}$ per liter, $\mathrm{pH}$ 6.8). The volume of buffer used was proportional to the mass of tissue processed. Afterwards the bags were subjected to one minute of manual squashing to release the microbes from the surface of leaves. Serial dilutions from each sample were plated onto KBC medium to determine the population size of $P$. syringae.

Plates were incubated for up to 3 days at $22-25{ }^{\circ} \mathrm{C}$. Production of fluorescent pigment on KBC was checked at 2 days after incubation with a long wavelength ultraviolet lamp (356 nm) and definitive counts of fluorescent and total colonies were realized after 5 days of incubation. Fluorescent colonies were transferred to $\mathrm{KBC}$ medium and the absence of cytochrome $\mathrm{C}$ oxidase was verified by streaking single colonies of a $48 \mathrm{~h}$ culture with a sterile toothpick onto filter paper imbibed with a fresh solution of $1 \% \mathrm{~N}, \mathrm{~N}, \mathrm{~N}, \mathrm{~N}$, tetramethyl-pphenylenediamine dihydrochloride (Sigma Chemical Company, Munich, Germany). The presence of arginine dihydrolase was tested as previously described by (Lelliot et al., 1966).

Out of the 25 genotypes of bread wheat leaves, 20 genotypes showed bacterial colonization but only 12 of the strains isolated proved to be $P$. syringae (Table 1 and 2). 
Table 1. Population density of P. syringae like bacteria on bread wheat leaves.

\begin{tabular}{cccccc}
\hline Code & Genotype name & $\begin{array}{c}\text { Population size }(P . \\
\text { syringae })\end{array}$ & Code & Genotype name & $\begin{array}{c}\text { Population size }(P . \\
\text { syringae })\end{array}$ \\
\hline $22 / 1$ & Gonglase-1 & ND $^{2}$ & $234 / 1$ & Massira/Jadida-2 & 4.38 \\
$22 / 2$ & Gonglase-1 & 5.32 & $234 / 2$ & Massira/Jadida-2 & 5.38 \\
$23 / 1$ & Weaver \Jacana & ND & $292 / 1$ & Faris-16 & 4.92 \\
$115 / 1$ & Pearl-10 & 3.33 & $306 / 1$ & Leith-4 & 3.43 \\
$122 / 2$ & Zad-1 & 5.36 & $338 / 1$ & Baasha-29 & ND \\
$122 / 3$ & Zad-1 & 5.48 & $349 / 3$ & Ghali-2 & 5.91 \\
$128 / 1$ & Alshoroq-1 & 2.98 & $364 / 2$ & Zafir-5 & 5.62 \\
$128 / 3$ & Alshoroq-1 & 5.62 & $369 / 1$ & N-Azraq-7 & ND \\
$133 / 2$ & Samira-20 & 4.77 & $369 / 3$ & N-Azraq-7 & ND \\
$185 / 1$ & Sabah-1 & 4.41 & $472 / 1$ & Alshoroq-1 & 4.70 \\
$306 / 3$ & Leith-4 & 5.18 & $472 / 2$ & Alshoroq-1 & 4.11 \\
$219 / 1$ & Anwar-1 & 3.02 & $499 / 1$ & Itir-2 & 3.67 \\
$219 / 2$ & Anwar-1 & 4.73 & & & \\
\hline
\end{tabular}

Evaluation of Host Range and Factors Related to Pathogenicity: $P$. syringae like strains isolated from seed were characterized for their host range, for traits related to pathogenicity, and for IN activity. Strains were considered to be $P$. syringae like if they produced fluorescent pigment on KB medium and gave negative responses in the tests for arginine dihydrolase and cytochrome $\mathrm{C}$ oxidase. Strains were purified and stored in $0.1 \mathrm{M}$ phosphate buffer at $4{ }^{\circ} \mathrm{C}$ and in $40 \%$ glycerol at $80^{\circ} \mathrm{C}$ before further testing.

The capacity of strains to induce a hypersensitive response was determined in tobacco by infiltrating, with a syringe, leaves of Nicotiana tabacum L. cv. Burley at the 10 leaf stage (bacterial suspensions of $48 \mathrm{~h}$ cultures, at approximately $1 \times 10^{8} \mathrm{CFU} \mathrm{ml}^{-1}$ ). Pathogenicity of each strain was determined on a range of field crops and vegetable crops representing a wide range of plant families and commonly grown in the dry land regions in the Middle East (Table 2): Bread Wheat (Triticum aestivum cv. Cham 4); Durum Wheat (Triticum durum cv. Cham 1); Barley (Hordeum vulgare cv. Arabi Aswad); Oat (Avena sativa cv. Local = not identified); Faba bean (Vicia faba cv. Romi); Lentil (Lens exculenta cv. Idleb 3); Chickpea (Cicer arietinum cv. Ghab 3); Pea (Pisum sativum cv. Local); Grass pea (Lathyrus sativus cv. Local) Coriander (Coriandrum sativum cv. Local); Cumin (Cuminum cyminum cv. Local); Black Seed (Nigella sativa cv. Local); and Tomato (Solanum lycopersicum cv. Local). Fifteen plants of each crop (three replicates of 5 plants) were inoculated with each strain (14 total strains) and were incubated under controlled conditions. Tomato is of particular interest for this study because, in Syria, it is subject to recurrent and serious blight caused by $P$. syringae. All treatments were inoculated at the two-leaf stage by abrading the leaves with a bacterial inoculum loaded toothbrush and then covering the leaves with plastic bags in light for 5-7 days at $22-25^{\circ} \mathrm{C}$. The inoculum consisted of aqueous suspensions of $48-\mathrm{h}$ bacterial cultures from KB plates adjusted to $3 \mathrm{X} 10^{8} \mathrm{CFU} \mathrm{ml}^{-1}$.

A well characterized non-pathogenic strain of $P$. syringae (R1) (resistant to rifampicin at $50 \mu \mathrm{g} \mathrm{ml}^{-1}$ ) was used as a negative control and sterilized distilled water was used as an additional negative control. Symptoms were recorded on a daily basis, and the reaction of the plant was scored at 7 days after inoculation, using the following previously described scale (Morris et al., 2000): 0 (no obvious symptoms); 1 (hypersensitive-like reaction restricted to the area of inoculation); 2 (slight expansion of a necrotic zone of tissue away from the area of inoculation and/or necrosis and breaking of the petiole); and 3 (expansion of a necrotic zone of tissue away from the area of inoculation, leading to wilting or death of the entire leaf or the entire plant). Bacteria were re-isolated from selected plants to confirm their presence by taking samples from the infected tissues, macerating in distilled sterilized water and spreadplating on KBC medium.

Production of syringomycin was evaluated on Nutrient Agar medium (Gross, 1985), according to the bioassay based on the sensitivity of Geotrichum candidum (Gross and DeVay, 1977). The distance between the border of the bacterial colony and the edge of the fungal lawn (zone of inhibition) was measured after 3 and 6 days of incubation. Ice-nucleation activity at -2 to $-8{ }^{\circ} \mathrm{C}$ was assessed with 30 
$\mu \mathrm{L}$ drops of aqueous bacterial suspensions containing a total of $10^{7}$ cells as described before (Morris et al., 2008).

Efficiency of Transmission of INA Strains of $\boldsymbol{P}$. syringae from Artificially Inoculated Seeds to Cotyledons: The ability of $P$. syringae to be transmitted from seeds to seedlings was determined with two seed treatment methods using four lines of $P$. syringae and six bread wheat genotypes obtained from the bread wheat breeding program at ICARDA (Giza-168, Daira-14, Reyna-8, Seri.1B, Karawan-1/Mellal-1, and Massira/Jassira/Jadida-2). To monitor the bacteria after inoculation into seeds, lines of parental strains were selected that were resistant to rifampicin $\left(50 \mu \mathrm{g} \mathrm{ml}^{-1}\right)$. Three rifampicin-resistant lines from strain CC1504 (referred to as R1, R2 and R3) and one resistant line from strain TA0043 (referred to as R043) were isolated. The parental lines are ice nucleation active and incapable of inducing hypersensitivity and were isolated from environmental sources as described previously (Berge et al, 2014).

The strains were grown on KBC medium and incubated at $22-25{ }^{\circ} \mathrm{C}$ for $48-50$ hours. The bacterial cells were washed off using a $0.1 \mathrm{M}$ phosphate buffer solution with carboxymethyl cellulose sodium salt $(0.5 \%)$ (SigmaAldrich) and transferred to sterilized test tubes; a mixture of the four lines of rifampicin-resistant bacteria was prepared as an additional treatment, giving a total of 6 treatments including the control treatment. The final concentration for each strain was determined by dilution plating on KBC medium.

The seeds were treated with the bacterial suspension using two methods: The first method consisted of coating seeds with a mixture of bacterial suspension and talcum powder. For this method, $1 \mathrm{ml}$ of bacterial suspension (final concentration $1 \mathrm{X} 10^{7} \mathrm{CFU}$ ml-1)from each strain was added to 15 seeds (3 replicates) in a sterile flask (in average $6.5 \mathrm{X} 10^{5} \mathrm{CFU} / \mathrm{seed}$ ), then the talcum powder was added gradually (about $1 \mathrm{~g}$ ) with shaking. The flasks were wrapped in aluminum sheets and transferred immediately to the greenhouse for planting. For the control treatment, seeds were treated with a $1 \mathrm{ml}$ solution of sterile 0.1 molar phosphate buffer with talcum powder. The second method consisted of soaking the seeds in a bacterial suspension: the seeds were treated with the same bacterial suspension in the same way as for the first method but they were then incubated at $22-25{ }^{\circ} \mathrm{C}$ overnight. On the next day talcum powder was added gradually. The control seeds were treated with a solution of $1 \mathrm{ml}$ of phosphate buffer and talcum powder incubated at $22-25^{\circ} \mathrm{C}$ overnight and then transferred to the a greenhouse for planting.

For each inoculation method, three replicates of 10 seeds were treated. Seeds were sown in $10 \mathrm{~cm}$ pots containing soil, sand and organic matter at 2.7:1.3:1 (v:v:v). This mixture was disinfected in an autoclave at $121{ }^{\circ} \mathrm{C}$ for $20 \mathrm{~min}$ prior to sowing. Sown seeds were incubated at $22-25{ }^{\circ} \mathrm{C}$ until germination, after which each pot was covered with a nylon bag to prevent the transmission of bacteria between treatments. Pots were irrigated with low water influx on the soil surface.

At 15 days after germination, pots were transferred to the laboratory to determine the presence of $P$. syringae on leaves either by dilution plating to measure the population density of the bacteria or by evaluating the IN activity of the leaf tissue and $0.4 \mathrm{~g}$ from the upper half of leaves of all plants in the same pot were sampled, macerated in test tubes containing phosphate buffer 0.1 $\mathrm{M}(10 \mathrm{ml})$, agitated for $1 \mathrm{~min}$ and stored in the refrigerator at $4{ }^{\circ} \mathrm{C}$. To determine the abundance of $P$. syringae on leaves, three tenfold dilutions were prepared and plated on KBC medium and incubated for up to 5 days at $22-25{ }^{\circ} \mathrm{C}$. The definitive counts of fluorescent and total colonies were realized after 5 days of incubation of plates. Ice nucleation activity was revealed by determining the freezing temperature of the suspensions, from -2 to $-9{ }^{\circ} \mathrm{C}$, by immersing the test tubes containing the leaf pieces in a cooling bath (3 replicates per strain and per genotype). The negative control was the suspension of control treatment leaves.

Verification of Bacterial Transmission from Leaves to Seed: The plots which showed bacterial colonization by Pseudomonas syringae on leaves were harvested and tested to study the transmission of the bacterium from leaves to seeds. This step was performed to evaluate the sustainability of the cycle of transmission of $P$. syringae from seed to leaves to seeds.

Two methods to isolate bacteria from seeds were applied to validate transmission, 1) seed soaking and 2) direct plating. For the seed soaking method, 1000 seeds from each genotype that showed P. syringae colonization of leaves (12 genotypes) were soaked in cold $0.85 \% \mathrm{NaCl}$ (saline) containing $0.02 \% \mathrm{v} / \mathrm{v}$ Tween 20 (Sigma) and incubated at 4 ${ }^{\circ} \mathrm{C}$ overnight $(16 \mathrm{~h})$. After shaking vigorously for about $1 \mathrm{~h}$, the sample was allowed to settle for $1 \mathrm{~min}$ and then tenfold dilutions in cold sterile saline were plated on KBC medium. The direct seed plating method was implemented also by placing 250 seeds (25 seeds per plate). Before plating, 
seeds were treated with running tap water (nonchlorinated) and air dried. Colonies that produced a diffusible fluorescent pigment after 3-4 days incubation at 22- $25{ }^{\circ} \mathrm{C}$ were collected, purified and stored in $0.1 \mathrm{M}$ phosphate buffer at $4{ }^{\circ} \mathrm{C}$ and in $40 \%$ glycerol at $-80{ }^{\circ} \mathrm{C}$, and later confirmed by physiological tests (absence of arginine dihydrolase and cytochrome $\mathrm{C}$ oxidase as described above) to be strains of $P$. syringae. The percent of the population that was recovered was estimated for the plating method and the population density on seeds (CFU/g) was estimated for the soaking method.

\section{RESULTS}

Natural Populations of $P$. syringe on Leaves of Bread Wheat Breeding Lines in Syria: Natural populations of $P$. syringae on wheat leaves were highly variable depending on the wheat genotype (Table 1) with some genotypes $(128 / 3,349 / 3,364 / 2)$ supporting high populations of $P$. syringae, while on other genotypes the populations were much lower (genotypes 128/1 and 219/1).

Out of the 25 bacteria strains obtained from leaf samples, 12 were shown to be $P$. syringae. Interestingly, the majority of the strains isolated $(8 / 12)$ could not induce hypersensitivity on tobacco (Table 2.). Nearly all $(7 / 8)$ of these strains came from lines of wheat that harbored population densities of $P$. syringae on their leaves of at least $10^{4} \mathrm{CFU} \mathrm{g}^{-1}$ and as high as $4 \times 10^{5} \mathrm{CFU} \mathrm{g}$ 1 (line 128/3).

Table 2. Traits of $P$. syringae like bacteria isolated from bread wheat leaves.

\begin{tabular}{|c|c|c|c|c|c|c|c|c|c|c|c|c|c|c|c|c|c|c|}
\hline \multicolumn{6}{|c|}{ Physiological traits } & \multicolumn{13}{|c|}{ Host Range $^{a}$} \\
\hline 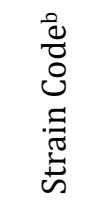 & 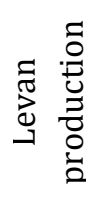 & 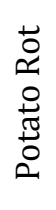 & 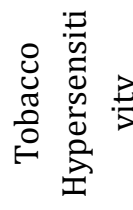 & 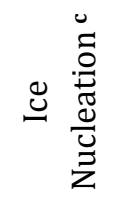 & 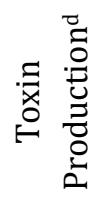 & $\begin{array}{l}\frac{1}{\pi} \\
\frac{0}{3} \\
\frac{1}{3} \\
0 \\
0 \\
0 \\
0 \\
0\end{array}$ & 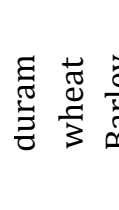 & & $\vec{\pi}$ & 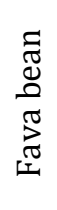 & 䄊 & 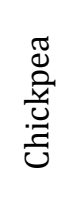 & $\begin{array}{l}\pi \\
0 \\
0 \\
0 \\
0 \\
0 \\
0 \\
0\end{array}$ & $\stackrel{\tilde{\Perp}}{\beth}$ & 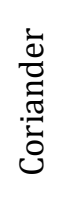 & 节 & 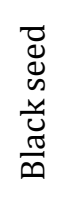 & 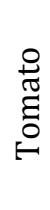 \\
\hline $22 / 2$ & + & - & + & $-6^{\circ} \mathrm{C}$ & 5 & & & & & & & & & & & & & \\
\hline $115 / 1$ & - & + & - & $-5^{\circ} \mathrm{C}$ & 13 & & & & & & & & & & & & & \\
\hline $122 / 2$ & - & + & - & $-6^{\circ} \mathrm{C}$ & 0 & & & & & & & & & & & & & \\
\hline $122 / 3$ & - & + & + & $-5^{\circ} \mathrm{C}$ & 17 & & & & & & & & & & & & & \\
\hline $128 / 3$ & - & + & - & $-5^{\circ} \mathrm{C}$ & 0 & & & & & & & & & & & & & \\
\hline $133 / 2$ & + & - & - & $-5^{\circ} \mathrm{C}$ & 8 & & & & & & & & & & & & & \\
\hline $234 / 1$ & + & - & - & $-4{ }^{\circ} \mathrm{C}$ & 23 & & & & & & & & & & & & & \\
\hline $234 / 2$ & + & - & + & $-5^{\circ} \mathrm{C}$ & 13 & & & & & & & & & & & & & \\
\hline $292 / 1$ & + & - & - & $-4^{\circ} \mathrm{C}$ & 18 & & & & & & & & & & & & & \\
\hline $306 / 3$ & + & + & - & $-4^{\circ} \mathrm{C}$ & 0 & & & & & & & & & & & & & \\
\hline $472 / 2$ & + & + & + & $-5^{\circ} \mathrm{C}$ & 0 & & & & & & & & & & & & & \\
\hline $499 / 1$ & + & - & - & $-4^{\circ} \mathrm{C}$ & 13 & & & & & & & & & & & & & \\
\hline
\end{tabular}

a. Pathogenicity was considered positive if more than half of the inoculated plants gave compatible reactions of score 3 (black squares) or score 2 (medium grey squares). Some strains caused compatible reactions on some plants, but fewer than half of the plants tested (light grey squares) and some strains never caused compatible reactions (white squares).

b. The origin of strains is indicated by the sample code. These codes are indicated in Table 1.

c. Ice nucleation activity (INA). For each strain, 3 droplets of $30 \mu \mathrm{L}$ of an aqueous suspension containing 107 cells per droplet were tested at temperatures of $1^{\circ} \mathrm{C}$ intervals from $-2 \mathrm{C}$ to $-8 \mathrm{C}$. Freezing was considered positive when at least 2 of the 3 droplets froze.

d. The width $(\mathrm{mm})$ of the zone of inhibition against Geotrichum candidum is indicated.

The incapacity to induce hypersensitivity in tobacco was not necessarily an indication of the absence of pathogenicity in $P$. syringae as has been observed elsewhere (Bartoli et al., 2014; Demba Diallo et al., 2012). Host range of the strains was highly variable, spanning from one host (strain 234/1) to all of the plant species and cultivars tested (strains 133/2 and 272/1). Although the strains that could not induce hypersensitivity in tobacco included those with the most restricted host range (234/1 and 128/3), they also included the strains with the broadest host range. 
The Inoculation of Wheat Seed with INA Strains of $P$. syringae Assures the Transfer of Bacteria to Seedlings: For these trials, the movement of strains from inoculated seeds to leaves of seedlings was verified by using spontaneous variants of strains that were resistant to the antibiotic rifampicin. Selection and characterization of these bacterial variants was time-consuming. Therefore, the strains of $P$. syringae used for this part of the study came from previous work as described above. The capacity of $P$. syringae to move from the seed to the seedling depended on the strain of the bacterium and on the genotype of the wheat (Table 3). Strain R1 was able to move from the seed to seedlings of all wheat genotypes, attaining population densities up to $10^{6} \mathrm{CFU} \mathrm{g}^{-1}$. Strains R2 and R3 were more inconsistent in their capacity to move from seeds to seedlings and R043 was not detected on Table 3. Populations of $P$. syringae on leaves and the concomitant IN activity of leaves from plants emerging from inoculated seed.

\begin{tabular}{|c|c|c|c|c|c|c|c|c|c|c|}
\hline \multicolumn{11}{|c|}{$\log _{10}$ mean population density of $P$. syringae $(\mathrm{CFU} / \mathrm{g}) /$ Warmest freezing temperature of $0.4 \mathrm{~g}$ leaf tissue pieces $\left({ }^{\circ} \mathrm{C}\right)$} \\
\hline \multirow{2}{*}{$\begin{array}{c}\text { Strain } \\
\text { Treatment }\end{array}$} & \multicolumn{2}{|c|}{ R1 } & \multicolumn{2}{|c|}{$\mathrm{R} 2$} & \multicolumn{2}{|c|}{$\mathrm{R} 3$} & \multicolumn{2}{|c|}{ R043 } & \multicolumn{2}{|c|}{ Mixture } \\
\hline & Coating & Soaking & Coating & Soaking & Coating & Soaking & Coating & Soaking & Coating & Soaking \\
\hline Giza-168 & $3.7 /-8$ & $\mathrm{ND}^{1} /-8$ & ND /-8 & ND /-9 & $4.1 /-8$ & $\mathrm{ND} /-7.5$ & ND / -8 & ND / ND & $4.5 /-7$ & $3.8 /-9$ \\
\hline Daira-14 & $4.4 /-8.5$ & ND / -9 & $2.8 /-9$ & ND / -8 & $\mathrm{ND} / \mathrm{ND}$ & ND / -7 & $\mathrm{ND} / \mathrm{ND}$ & ND / -7 & $5.0 /-8$ & ND / -8 \\
\hline Renya-8 & $4.4 /-9$ & ND / -8.5 & ND / -8 & ND / -9 & $\mathrm{ND} /-7$ & ND / -8 & ND / -9 & $\mathrm{ND} / \mathrm{ND}$ & $4.7 /-7$ & $4.6 /-9$ \\
\hline Seri.1B & $6.1 /-9$ & $5.6 / \mathrm{ND}$ & $4.6 /-8$ & ND / -9 & $2.3 /-9$ & $3.9 /-8$ & ND / -9 & $\mathrm{ND} /-9.5$ & $6.8 /-7$ & $4.8 /-7$ \\
\hline Karawan-1 & $5.3 /-8$ & $\mathrm{ND} /-8$ & ND / -9 & ND / -9 & ND / -7 & ND / -8 & ND / ND & ND / -9 & $4.9 /-8$ & $5.4 /-8$ \\
\hline Massira & $5.6 /-9$ & $1.0 /-9$ & $1.9 /-8$ & ND / -8 & ND / - 9 & $\mathrm{ND} / \mathrm{ND}$ & ND / -9 & $\mathrm{ND} / \mathrm{ND}$ & $4.4 /-8$ & $5.8 / \mathrm{ND}$ \\
\hline
\end{tabular}

${ }^{1}$ Not detected. For populations on leaves the detection threshold was 7.5X $103 \mathrm{CFU} / \mathrm{g}$. For the IN test, freezing was reported as not detected if only 1 or no tubes froze in the range of temperatures tested $\left(-2^{\circ}\right.$ to $\left.-9^{\circ} \mathrm{C}\right)$.

Transmission of INA Bacteria from Wheat Leaves to Seeds under Natural Conditions: Among the 25 wheat genotypes tested in the field for epiphytic populations, only 12 carried $P$. syringae. The transmission of $P$. syringae to seeds harvested from these 12 genotypes was then determined. Seed-borne populations were assessed at two storage periods: immediately after seed harvest and after 3 months of storage.

Immediately after harvest $P$. syringae was detected on the seeds of all 12 genotypes, depending on the method of detection (Table 4). Interestingly, there was no apparent correlation of the size of the population on leaves in the field with the percent of seeds carrying $P$. syringae or with the size of the populations on the seed. After 3 months of storage, $P$. syringae was not detected on the seeds of any of the genotypes via the seed soaking method whereas it was detected on a small percent of the seeds for 6 of the genotypes via the direct plating method. In spite of the any seedlings by dilution plating. When detected, bacterial population densities varied up to 100 fold among the different plant genotypes with the Seri.1B genotype harboring the highest population densities on leaves. In ice nucleation assays, none of the leaf tissue emerging from seeds treated with sterile buffer froze in the range of temperatures tested. In contrast, nearly all of the leaf tissue collected from plants from seeds inoculated with $P$. syringae froze at $-9{ }^{\circ} \mathrm{C}$ or warmer suggesting that IN active cells of the bacterium were present even though they could not be detected with dilution plating. The warmest temperatures of freezing were not necessarily associated with the largest population densities of $P$. syringae on leaf tissue suggesting that there was an interaction of plant genotype and bacterial strain on IN rate of $P$. syringae. fewer seeds that were used in the direct plating method compared to the seed soaking method, the direct plating method was more efficient in detecting $P$. syringae most likely due to enhancement of bacterial growth by the presence of the seed on the plating medium.

\section{DISCUSSION}

Our results demonstrate that wheat breeding lines and cultivars adapted to dry land agriculture vary considerably in the number and diversity of $P$. syringae that populate their leaf surfaces both in terms of their potential as pathogens and as ice nuclei. These wheat lines also differ in their propensity for epiphytic P. syringae to be transmitted to and survive on the seed and subsequently for the colonization of leaves from seed-borne populations. Furthermore, there is a marked interaction between strains and wheat genotype in these processes. Interestingly, strains of $P$. syringae with little pathogenic potential and with marked IN activity at 
relatively warm temperatures $\left(>-10^{\circ} \mathrm{C}\right)$ were readily detected on the wheat phyllosphere and were transmitted from leaves to seeds and vise-versa. These results illustrate that wheat lines could be selected to favor the non-pathogenic IN active component of the indigenous microflora. Likewise they also suggest that the microflora of wheat could be further altered by inoculating seed with the strains of $P$. syringae that are most fit for colonization and with the least potential as pathogens and the most potential as ice nucleators. Overall, this work points to the possibility of selecting plants with the goal of changing their microflora for purposes other than resistance to plant disease. In this case we propose altering the microbiology of plant surfaces for the eventual effect that these microorganisms can have on the atmosphere when they are removed from plants by air turbulence and transported into the troposphere. All microorganisms on plant surfaces are susceptible to being released into the atmosphere, however the traits of plants that confer the intensity of this release are not currently considered in plant breeding. Selecting plants for enhanced microflora that render various ecological services could be extended to other services such as antagonistic biocontrol activity toward pathogens. For example, most of the strains of $P$. syringae characterized in this study produced a toxin that inhibited fungi, a trait that could potentially be useful in limiting certain fungal pathogens. Table 4. Detection of naturally occurring P. syringae on seeds of wheat from field-grown plants.

\begin{tabular}{|c|c|c|c|c|c|}
\hline \multirow{3}{*}{$\begin{array}{r}\text { Plant } \\
\text { genotype }\end{array}$} & \multirow{3}{*}{$\begin{array}{c}\text { Thousand seed } \\
\text { weight (g) }\end{array}$} & \multicolumn{2}{|c|}{ P. syringae on seeds ${ }^{1}$} & \multirow{2}{*}{\multicolumn{2}{|c|}{ at 3 months after harvest }} \\
\hline & & immed & after harvest & & \\
\hline & & $\mathrm{CFU}^{2} / \mathrm{g}$ & $\%$ infected seed & $\mathrm{CFU} / \mathrm{g}$ & \% infected seed \\
\hline $22 / 2$ & 49.5 & $>900$ & 40 & $\mathrm{ND}^{3}$ & ND \\
\hline $115 / 1$ & 55 & 150 & 10 & ND & ND \\
\hline $122 / 2$ & 53 & 690 & 20 & ND & ND \\
\hline $122 / 3$ & 53 & 160 & ND & ND & ND \\
\hline $128 / 3$ & 56 & 490 & 26 & ND & ND \\
\hline $133 / 2$ & 52.5 & 560 & 24 & ND & 2 \\
\hline $234 / 1$ & 57.5 & 870 & 64 & ND & 16 \\
\hline $234 / 2$ & 57.5 & 470 & 24 & ND & 1 \\
\hline $292 / 1$ & 49 & 530 & 16 & ND & 4 \\
\hline $306 / 3$ & 54 & 710 & 52 & ND & 1 \\
\hline $472 / 2$ & 51 & 300 & 18 & ND & ND \\
\hline $499 / 1$ & 53.5 & 330 & 56 & ND & 18 \\
\hline
\end{tabular}

${ }^{1}$ The presence of P. syringae on seed was determined either by dilution plating the buffer used to wash 1000 seeds (expressed as $\mathrm{CFU} / \mathrm{g}$ of seed) or by allowing bacteria to grow from 250 seeds place directly on nutrient medium (expressed as the \% of seeds carrying the bacterium).

${ }^{2}$ Colony-forming units

${ }^{3}$ Not Detected

Our results also illustrate that breeding and selection of wheat for traits such as yield or disease resistance could have inadvertently selected against abundance of IN active $P$. syringae or other biological IN active microorganisms. Direct selection against IN active $P$. syringae is likely when the size of populations that this bacterium can attain on leaves is correlated with resistance to disease caused by this bacterium as in the case of snap beans (Daub and Hagedorn, 1981). In regions where drought is a major limitation for crop production, it would be important to develop breeding and production strategies that protect crop health while fostering the contribution of plants to the water budget - in terms of tolerance to water limitation as well as contribution to the bioprecipitation cycle. As cultivated and managed land grew to represent $50 \%$ of the vegetated surface of Earth (Ellis et al., 2010), the areas of land planted to genetically homogenous crops has increased and in particular for the major staple crops. In the developing world this homogeneity has resulted mainly from the efforts of the major international agricultural research centers to offer farmers the necessary resources for assuring the best possible yields. Via the networks of these international research centers for distributing plant cultivars and monitoring their performance, the environmental impact of 
breeding plants to make beneficial contributions to the water cycle could be significant and could be set in a context where it could be evaluated on a large scale.

\section{CONCLUSIONS}

We have demonstrated that wheat breeding lines adapted to dry land agriculture vary in the size of the populations of weakly pathogenic and IN active $P$. syringae that they harbor on their leaves and in their capacity to transmit these bacteria to seeds and subsequently from seeds to leaves. Furthermore, we have also revealed a marked interaction between strains of $P$. syringae and the capacity of wheat breeding lines to foster leaf colonization and transmission from leaf to seed and back to leaves. This variability could be the basis of a breeding program that targets the development of wheat lines that contribute to the bioprecipitation cycle by generating aerosols of IN active bacteria that could favor rainfall under those conditions in clouds that are not favorable for other common atmospheric ice nuclei such dust and mineral particles to induce rain. Seed treatment with specific strains of $P$. syringae enhanced the colonization of leaves of certain wheat genotypes by these bacteria. Hence, the creation of plant cultivars that favor the abundance of IN active $P$. syringae could be coupled to seed inoculation methods in an attempt to develop a new generation of wheat lines adapted to dry land agriculture.

\section{REFERENCES}

Bartoli, C., O. Berge, C. L. Monteil, C. Guilbaud, G. M. Balestra, L. Varvaro, C. E. Morris. 2014. The Pseudomonas viridiflava phylogroups in the P. syringae species complex are characterized by genetic variability and phenotypic plasticity of pathogenicity-related traits. Environmental microbiology. 16(7): 2301-2315.

Berge, O., C. L. Monteil. C. Bartoli, C. Chandeysson, C. Guilbaud, D. C. Sands, and C. E.Morris, C. E. 2014. A user's guide to a data base of the diversity of Pseudomonas syringae and its application to classifying strains in this phylogenetic complex.

Brummer, E. C., W. T. Barber, S. M. Collier, T. S. Cox, R. Johnson, S. C. Murray, R. T. Olsen, R. C. Pratt and A. M. Thro. 2011. Plant breeding for harmony between agriculture and the environment. Frontiers in Ecology and the Environment. 9(10):561-568.

Daub, M. E. and D. J. Hagedorn. 1981. Epiphytic populations of Pseudomonas syringae on susceptible and resistant bean lines. Phytopathology. 71: 547-550.

Diallo, M. D., C. L. Monteil, B. A. Vinatzer, C. R. Clarke, C. Glaux, C. Guilbaud and C. E. Morris. 2012. Pseudomonas syringae naturally lacking the canonical type III secretion system are ubiquitous in nonagricultural habitats, are phylogenetically diverse and can be pathogenic. The ISME journal. 6(7): 1325-1335.

Ellis, E. C., K. K. Goldewijk, S. Siebert, D. Lightman and N. Ramankutty. 2010. Anthropogenic transformation of the biomes, 1700 to 2000. Global Ecol. Biogeogr. 19: 589-606.

Georgakopoulos, D. G. and D. C. Sands. 1992. Epiphytic populations of Pseudomonas syringae on barley. Can. J. Microbiol. 38: 111-114.

Gross, D. C. 1985. Regulation of syringomycin synthesis in Pseudomonas syringae pv. syringae and defined conditions for its production. J. Appl. Bacteriol. 58: 167-174.

Gross, D. C. and J. E. DeVay. 1977. Population dynamics and pathogenesis of Pseudomonas syringae in maize and cowpea in relation to the in vitro production of syringomycin. Phytopathology. 67 (4): 475-483.

Heisey, P. W. and M. A. Lantican. 2000. International Wheat Breeding Research in Eastern and Southern Africa 1966-1967, CIMMYT Economics Working Paper13 pages. Mexico. CIMMYT.

International Rules for Seed Testing (ISTA). 2008. Working sheet 7-023. Detection of Pseudomonas savastanoi pv. phaseolicola on Phaseolus vulgaris. The International Seed Testing Association (ISTA), Bassersdorf, Switzer-land.

Karrou, M., Oweis, T. and Bahri, A. (eds) 2011. Improving water and land productivities in rainfed systems. Community-Based Optimization of the Management of Scarce Water Resources in Agriculture in CWANA. Report no. 8. International Center for Agricultural Research in the Dry Areas (ICARDA), Aleppo, Syria. vi + 170 pp.

Lelliot, R. A., E. Billing and A. C. Hayward. 1966. A determinative scheme for the fluorescent plant pathogenic pseudo-monads. J Appl. Bacteriol. 29: 470-489.

Lindow, S. E., D. C. Arny and C. D. Upper. 1978. Distribution of ice nucleation-active bacteria on 
plants in nature. Appl. Environ. Microbiol. 36: 831-838.

Millenium Ecosystem Assessment. 2005. Ecosystems and Human Well-being: Desertification Synthesis: Key Questions on Desertification in the Millennium Ecosystem Assessment. Topic editor: Ed.-in-chief, Cutler Cleveland. Encyclopedia of Earth. National Council for Science and the Environment. Washington DC.

Mohan, S. K. and N. W. Schaad. 1987. An improved agar plating assay for detecting Pseudomonas syringae pv. syringae and P. s. pv. phaseolicola in contaminated bean seed. Phytopathology. 77: 1390-1395.

Morris, C. E., F. Conen, J. A. Huffman, V. Phillips, U. Poschl and D. C. Sands. 2014. Bioprecipitation: a feedback cycle linking Earth history, ecosystem dynamics and land use through biological ice nucleators in the atmosphere. Global Change Biology. 20: 341-351.

Morris, C. E., C. L. Monteil and O. Berge. 2013. The life history of Pseudomonas syringae: linking agriculture to Earth system processes. Annu. Rev. Phytopathol. 51: 85-104.

Morris, C. E., D. C. Sands, B. A. Vinatzer, C. Glaux, C. Guilbaud, A. Buffière, S. Yan, H. Dominguez and B.
M. Thompson. 2008. The life history of the plant pathogen Pseudomonas syringae is linked to the water cycle. ISME Journal. 2: 321-334.

Morris, C. E., C. Glaux, X. Latour, L. Gardan, R. Samson and M. Pitrat. 2000. The relationship of host range, physiology, and genotype to virulence on cantaloupe in Pseudomonas syringae from cantaloupe blight epidemics in France. Phytopathology. 90: 636-646.

Navarro, F., P. Skroch, G. Jung and J. Nienhuis. 2007. Quantitative trait loci associated with bacterial brown spot in Phaseolus vulgaris L. Crop Sci. 47 :1344-1353.

Qin, W., B. Chi, and O. Oenema. 2013. Long-term monitoring of rainfed wheat yield and soil water at the loess plateau reveals low water use efficiency.

Rajaram, S. 1995. Yield stability and avoiding genetic vulnerability in bread wheat. Wheat Breeding at CIMMYT. Commemorating. 50: 11-15.

Zhang, H., T. Y. Oweis, S. Garabet and M. Pala. 1998. Water-use efficiency and transpiration efficiency of wheat under rain-fed conditions and supplemental irrigation in a Mediterranean-type environment. Plant and Soil. 201: 295-305. 